\title{
Emerging Patterns of Authority in Early Shicism: al-Mukhtār and the Aesthetics of Persuasion
}

\author{
Torsten Hylén \\ Dalarna University, Sweden \\ thy@du.se
}

\begin{abstract}
In this study the author examines some aspects of authority in the movement of the Shicite leader al-Mukhtār (d. 67/687). The notion of religious aesthetics as developed by Birgit Meyer is used as an analytical tool. It is argued that al-Mukhtār accomplished his political endeavour partly by introducing and controlling three "aesthetic forms" which functioned as "media" between the people and the deceased 'Alī b. Abī Ṭālib: his claim to act on behalf of 'Alī's son Ibn al-Hanafiyya, whom he called al-mahdī, "the rightly guided"; his call to revenge for the killing of 'Alī's son Ḥusayn; and his exhibiting of a chair that he claimed had belonged to 'Alī. The accounts of these three media, the author furthermore argues, have an historical foundation. Finally he holds that through these media al-Mukhtār was able to channel the needs and aspirations of many of the Shiites of Kufa into political action.
\end{abstract}

\section{Keywords}

Mukhtar - Shi'ism - authority - Birgit Meyer - religious aesthetics

\section{Introduction $^{1}$}

The movement of al-Mukhtār b. Abī 'Ubayd al-Thaqafì (d. 67/687) is one of the most fully recorded groups in the first century of Islam, and also one that has

1 This article is one of the fruits of the research project "Negotiating authority in contemporary Shiite thought and practice" funded by the Swedish Research Council (reg. no. 421-2012-822). I am grateful to comments and feedback from the research group. I also want to thank the 
been thoroughly investigated by modern scholarship. ${ }^{2}$ The reason for its prominence is, firstly, that it was a politically important movement that challenged the two main contenders for power during the last decade of the seventh century CE: the Umayyad caliphate, based in Damascus, and the caliphate of 'Abd Allāh b. al-Zubayr, centred on Mecca. Secondly, the movement of al-Mukhtār is important for the study of the development of the Shicite ideology, as several of the concepts and ideas that were promoted by him and his companions were later developed and are visible even in Shi'ism today. But why did he succeed in raising a support strong enough to challenge the two caliphates? In the present study, I will examine some aspects of authority in this movement and point to what I believe is one factor (out of several) for his achievement. These features will be investigated with the help of the concept of religious aesthetics developed by the German anthropologist Birgit Meyer and others. The reason I have chosen her theory about religious aesthetics in my analysis of al-Mukhtār is that it can help us understand how he was able to gain such a degree of authority.

In Meyer's studies, aesthetics is taken in its old, Aristotelian meaning. Thus, Aristotle

understood our perception of the world through our five senses as an undivided whole. This is what he meant by aisthesis ...: our corporeal capability on the basis of a power given in our psyche to perceive objects in the world via our five different sensorial modes, thus in a kind of analytical way, and at the same time as a specific constellation of sensations as a whole (e.g., an apple with a texture, a taste, a smell, a sound, and a visible shape and color). An apple makes an impression or has an impact (on us) as a whole and in different sensorial ways at exactly the same time.

Aisthesis then refers to our total sensorial experience of the world and to our sensuous knowledge of it. ${ }^{3}$

two anonymous readers, and my colleague at Dalarna University, Dr Therese Rodin, for invaluable comments. Any remaining mistake in the article is my own responsibility.

2 Some important studies of al-Mukhtār and his movement from different perspectives are Anthony, The Caliph, pp. 256-290; "Kaysāniya"; Dixon, Umayyad Caliphate, pp. 25-81; Fishbein, "Life of al-Mukhtār"; Hawting, "Al-Mukhtār"; Qadi, Al-Kaysānīya, pp. 71-137; Wellhausen, Oppositionsparteien, pp. 74-95. These studies are of shifting quality; some (notably Anthony, The Caliph) are truly critical in the sense that they investigate and problematize the sources according to criteria normally used in modern academic scholarship; others (particularly Wellhausen and Dixon) are mainly compilations and attempts to harmonise the sources.

3 Meyer and Verrips, "Aesthetics," p. 21. 
Meyer applies this concept to religion in contrast to the post-enlightenment understanding, according to which religion is confined to the mind. Thus, she holds that religion affects the whole human being, both body and mind, and writes that

[i]n order to be present in the world ... religion requires tangible, sensational forms. Therefore, one should analyze religion as offering a particular aesthetics, provided we ... ground our understanding of aesthetics beyond the body-mind divide. ${ }^{4}$

Meyer regards religion as "a practice of mediation" that bridges the gap between the temporal and the perceived divine. ${ }^{5}$ This bridging is accomplished through various kinds of media such as persons, artefacts, texts, and actions that create in the believers sensational experiences of the transcendent. Meyer argues that the person who controls such media can "distribute" the experiences, and thus obtains authority. ${ }^{6}$

In the present study, I will investigate three such media employed by alMukhtār to channel and remould the veneration for 'Alī b. Abī Țālib, the cousin and son in law of the Prophet Muhammad, into a means to support his own authority: his claim to act on behalf of one of 'Alì's sons, Muhammad b. alHanafiyya; his promise to avenge the death of Husayn, another of 'Alì's sons; and his claim that he was in possession of a relic from 'Alī, a chair that he claimed the latter had used in his lifetime.

The use of theory developed within the social sciences is not commonplace in studies of early Islam. This is unfortunate, for it has proved fruitful in many other fields of historical research. As the New Testament scholar Paula Fredriksen says: "The hope in using theory is that we can wring more information from our data". ${ }^{7}$ In other words, theories and methods developed through studies on modern societies within disciplines such as sociology, economics, and anthropology can help us interpret data also from ancient times. Fredriksen continues:

... the method we use, by organizing our sparse data according to its criteria, holds out the promise of helping us perceive motives or meanings

4 Meyer, "Aesthetics of Persuasion," pp. 749-750.

5 Meyer, "Religious Revelation," pp. 435-437; see also Meyer and Verrips, "Aesthetics," p. 25.

6 I will give further details on Meyer's theory towards the end of the article.

7 Fredriksen, From Jesus to Christ, p. xvii. In the context from which the quote is taken, the author does not distinguish between theory and method; both are important. 
or social dynamics that are disguised, only implied, or perhaps otherwise invisible in the record once our positive evidence runs out. The method provides a "plot" by which we can organize our data into a story. ${ }^{8}$

Although she cautions against the excessive use of such theories, she gives several examples where it has been fruitful in the field of Biblical Studies and Early Church History. Likewise, I think that the scarcity of data from early Islam can to some extent be supplemented by conclusions drawn from similar situations in modern times through the help of such theories.

\section{Methodological Considerations}

Birgit Meyer has developed her theory and the concepts related to it during her studies on Pentecostals in Ghana in the past decades. The question is whether it is at all possible to translate a modern anthropological theory to make it applicable to events related in historical documents from a totally different culture in the seventh and eighth centuries CE: accounts in historical documents based on reports given at third or fourth hand. If the events analysed are mere literary constructs, a theory like Meyer's cannot be used. The first problem with this kind of study, then, is that of determining the historicity of the events related. Hence, while describing the three media used by al-Mukhtār, I will argue that the accounts of them in the sources probably have a historical basis.

A very substantial body of scholarship, particularly since the 1970s, has demonstrated that early Islamic historiography cannot be taken at face value. ${ }^{9}$ Just as present-day historians, medieval Muslim scholars were influenced by the culture and values of their contexts. This affected their views of history and the events that had occurred. Thus, texts from the history of Islam have to be carefully analysed in order to sift out the biases of later historians that have accumulated upon the earliest versions (which in themselves, of course, are accounts given from particular perspectives). As previous research has demonstrated, accounts with a historical basis are often merged with traditions of a more spurious character that are religiously or politically biased. Hence, the basis in historical fact must be investigated from case to case. Space constraints make it

8 Ibid., p. xviii.

9 Among the many works that have been published on this, here are only a few examples that give an overview of the field of Islamic historiography and the modern discussion about it; each of them have many references to other works: Noth and Conrad, Early Arabic Historical Tradition; Donner, Narratives, pp. 1-31; Robinson, Islamic Historiography, in particular, Chapter 2; Gilliot, “Débat”. 
impossible to present detailed arguments for the historicity of the events and notions discussed in the present study. I will however offer two basic criteria for the historicity of the cases discussed here.

First, an event is more likely to be historically based if several sources that are mutually independent relate the same thing and/or if the same event is accounted for or echoed in different forms of literature. An example, which will be more elaborated below, is the wish expressed by al-Mukhtār to take vengeance for the killing of Husayn, which is narrated by Abū Mikhnaf, Ibn Sadd, and al-Dīnawarī, probably independently of each other. That this idea was actually expressed by al-Mukhtār rather than being a motif associated with him by later tradition is strengthened by its occurrence in poems by contemporary poets. ${ }^{10}$ Secondly, words or actions that would have created embarrassment for the later community are likely actually to have occurred. This argument applies to the appearance in the narrative of a chair which, it was claimed, had been used by 'Alī, which became an object of cult to some of the followers of al-Mukhtār. Others regarded the cult of the chair as blasphemous. It subsequently disappeared suddenly, never to be heard of again. The chair of 'Ali will be further discussed below.

\section{Shi' ite Developments before al-Mukhtār}

What united many of those who called themselves Shicites was the idea that 'Alī b. Abi Țâlib, the cousin and son in law of the Prophet Muhammad, was the rightful successor, the legatee (Ar. wașī) of the Prophet. ${ }^{11}$ They were also in constant opposition to other contestants for the political power, in particular the Umayyads, who were regarded as usurpers. It seems clear that very earlyprobably already during his lifetime - some groups had a considerably higher esteem of 'Alī than as a mere political leader, and regarded him as what AmirMoezzi calls "a semi-legendary figure of heroic and even sacred dimensions". ${ }^{2}$

10 A more extensive discussion of this criterion and its application on the movement of alMukhtār is found in Hylén, "Mukhtār and the Mahdī," pp. 145-148.

11 In this context I use the term 'Shi'ites' for the sake of convenience, although the sprawling movement had not yet crystallised and adopted many of the tenets that later Shicism is famous for.

12 Amir-Moezzi, "Dìn 'Alı̄," p. 44. The view that 'Alī had a special position in the minds of many of his followers from a very early stage is advanced by several scholars; see e.g. Anthony, The Caliph, passim; Dakake, Charismatic Community, pp. 33-69; Kohlberg, “Ṣahāba," pp. 145-146; Qadi, “The Term Ghulāt," pp. 295-301. 
This veneration of him was often referred to as $\operatorname{din}$ 'Ali, "the religion of 'Ali". 13 Furthermore, immediately after his murder in 40/661 some Shi' ites, in particular the group that came to be called the Saba'iyya, seems either to have denied that he had died, or expected him to return from death. ${ }^{14}$

A couple of decades after the death of 'Alī, his son Husayn was prepared to enter the political arena. The Shi ites of Kufa asked Husayn to leave Mecca and come to their town and lead them in an insurrection against the Umayyad governor there. ${ }^{15}$ When he was informed that his following in the town was massive and it would be safe to come to Kufa, he set off. But while he was on the long journey, the new governor of Kufa, 'Ubayd Allāh b. Ziyād, bribed and intimidated those that had pledged their allegiance to Husayn into withholding their support from him. In Muharram 61/October 68o, Husayn and his little group (consisting of perhaps a hundred people: men, women, and children) were intercepted by a large army at Karbalā', North West of Kufa, and cut off from all access to water. He first tried to negotiate with the enemy, but when this proved futile the only choice was to fight. Husayn and most of his family and followers were killed.

Immediately after the death of Husayn, many of those who had pledged to support him, but who failed to come to his help, felt deep guilt for their betrayal. One of the first expressions of this guilt is seen in the movement of the Penitents (Ar. Tawwābunn). ${ }^{16}$ Some of the men who had failed to support him gathered and decided that they would take to arms and go against the Umayyad army; to kill those that had killed Husayn, or be killed themselves in the attempt to find revenge for him. The Penitents were well aware that this act in all probability would lead to their own deaths, but they regarded it as an act of martyrdom for the cause of the loyalty to the Prophet and his offspring, and

13 Amir-Moezzi, "Dìn 'Alı".

14 Anthony, The Caliph, pp. 313-317; Qadi, “The Term Ghulāt," pp. 300-301; Amir-Moezzi, "Muhammad le paraclet," pp. 44-45. For a discussion of the doctrine of raj'a (returning from the dead) in early Shi'ism, see Amir-Moezzi, "Raj'a"; van Ess, Theologie und Gesellschaft, vol. 1, pp. 285-287, 290-298.

15 The following summary of the Karbalā' tragedy is based on the sources given by al-Tabarī Tärīkh, ser. II, pp. 216-39o. The text is translated by I.K.A. Howard in al-Tabarī, History, vol. XIX, pp. 1-183. For a survey of the sources, see Borrut, "Remembering Karbalā". For more comprehensive summaries of the story see e.g. Haider, Shī Islam, pp. 66-81; Hylén, "Husayn, the Mediator," pp. 205-217; Jafri, Origins, pp. 174-221; Veccia Vaglieri, "Husayn".

16 The most complete version of the story of the Penitents is found in al-Tabarī, Tärīkh, ser. II, pp. 497-513, 538-578; Eng. tr. by G. Hawting in al-Ṭabarī, History, vol. XX, pp. 8o97, 124-16o. For summaries in translation, see Wellhausen, Oppositionsparteien, pp. 71-74; Halm, Shi'a Islam, pp. 16-20; Calmard, “Culte," pp. 66-69; Jafri, Origins, pp. 222-234; Dakake, Charismatic Community, pp. 90-95. 
thought that it would cleanse them from their offense. They set out in Rabī II 65/November 684, eventually met the Umayyads at 'Ayn al-Warda in northern Iraq, and were defeated. Some of the few survivors felt great shame that they were not killed in the campaign.

On the wider political arena, things became increasingly disturbed at this time. Soon after the death of the Umayyad caliph Yazīd b. Mu'āwiya in 64/683, the Meccan aristocrat 'Abd Allāh b. al-Zubayr conquered all of the Hijāz, southern Iraq, and the Western areas of Iran. From Mecca he claimed the caliphate for himself, and installed governors in the important towns of his empire, including Kufa. Thus, for about a decade (64-73/683-692), there were two caliphates competing for power over the entire region: one in the south with Ibn al-Zubayr as caliph in Mecca, and one in the north where members from the Umayyad family in Damascus claimed the authority for themselves. ${ }^{17}$

Many scholars agree that in the period between the Prophet Muhammad and the beginning of the eighth century, apocalyptic ideas flourished in this part of the world. ${ }^{18}$ In some groups, notably those that held 'Ali in high esteem, such ideas were very prominent. In his study of the early Shi ite group called the Saba'iyya, Sean Anthony discusses their idea that 'Ali was not dead but would return - his raj'a — and demonstrates that this notion had obvious messianic overtones. ${ }^{19}$ Many of these ideas were common in Jewish, Christian, and other apocalyptic thought at the time, and had been appropriated and adapted by the Saba'iyya movement. Anthony maintains that several themes can be historically verified as belonging to this group: the denial of the death of 'Alī and the belief in his return; the motive that he would gain a messianic victory over the enemies of God while carrying the lost staff of Moses; and the identification of him with the apocalyptic beast (dābba min al-ard ) mentioned in the Qur'an 27:82. ${ }^{20}$ But, Anthony further argues,

the full extent of Jewish influence (or Christian, Zoroastrian and Manichaean for that matter) on early Islam cannot be localized or limited

17 Hawting, First Dynasty, pp. 46-57; Robinson, Abd al-Malik, pp. 35-39.

18 S ee e.g. Arjomand, "Apocalypticism," pp. 238-257; Crone, Political Thought, pp. 75-80; Donner, Muhammad and the Believers, pp. 78-82; Anthony, The Caliph, pp. 224-225. By "apocalyptic" I mean ideas about the imminent end of the world and the signs preceding it.

19 Anthony, The Caliph, pp. 195-225.

20 Ibid., p. 218. The notion of the beast is probably an influence from apocalyptic texts in the Bible (Dan. 7:1-8; Rev. 13). In contrast to the beast in Christian tradition, however, the Islamic dābba is often regarded as benevolent; see Arjomand, "Apocalypticism," pp. 239240. Hence it was possible to identify it with 'Alī. 
within the confines of a singular sectarian trend.... These sorts of influences were, rather, pervasive and much more mutual and dialectic than has, until very recently, been appreciated.... These symbols, mythemes, prophesies, etc. were "in the wind" and somehow - the fog of historical distance hinders our ability to find these intermediaries - they came to be attached to the person of 'Alī and the hopes and ambitions of his partisans. ${ }^{21}$

Thus, ideas that can be called "messianic" were associated with 'Alī from a very early period, and although many Shi ites objected to them, at least in their more extreme forms as can be seen from the sources, they were quite widespread. ${ }^{22}$

\section{Al-Mukhtār and His Movement}

Following the defeat of the Penitents in 65/685, al-Mukhtār b. Abī 'Ubayd alThaqafi- the main focus of the present study—rose to power as the most prominent political leader of the Shicites. ${ }^{23}$ The sources often regard him with great suspicion, describing him as a political opportunist more interested in power than in adhering to political or religious convictions. Al-Mukhtār claimed to have been sent by a living son of 'Alī, Muhammad b. al-Hanafiyya. Ibn al-Ḥanafiyya was 'Alī's son, not (like Ḥasan and Ḥusayn) with Fāțima the daughter of the Prophet, but with a slave woman from the tribe of Hanifa; hence his appellation Ibn al-Hanafiyya ("the son of the Hanafĩ woman"). He seems to have been very hesitant, if not outright negative to being associated with al-Mukhtār. The latter, however, called Ibn al-Ḥanafiyya al-mahdī, "the rightly guided" ${ }^{24} \mathrm{He}$ gathered around him a great number of Shi ites, to a large extent consisting of two categories: mawā $\bar{\imath}$ (non-Arab clients to an Arab tribe), and members of South Arabian tribes who had settled in Kufa.

Most sources attest the great amount of mawāli (sg. mawlā) among the supporters of al-Mukhtār. ${ }^{25}$ Pre-Islamic Arab society was based on a system of

21 Anthony, The Caliph, pp. 224-225. But cf. Cameron, "Late Antique Apocalyptic" for a more cautious approach to the phenomenon of apocalypticism in Late Antiquity.

22 On this issue, see now also Amir-Moezzi, "Muhammad le paraclet".

23 In the following account I relate only details that are supported by at least two independent sources. For a discussion of the historicity of various elements of the story, see below.

24 I will discuss the different meanings of this term below. See also Hylén, "Mukhtār and the Mahd $\vec{\imath}$.

25 See e.g. Crone, Political Thought, p. 85; Fishbein, "Life of al-Mukhtār," pp. 15-42; Urban, "Early Islamic Mawā lı̆, pp. 98-104. 
genealogically defined tribes. Membership in a tribe was necessary in order to be part of society. ${ }^{26}$ Those who were not born into a tribe could become a member of society only by becoming affiliated to a tribe in a kind of contractual relationship; by becoming a mawlā to an Arab belonging to a tribe, a person could thereby become connected to that tribe. The mawāli thus comprised all non-Arabs who were part of the society, including freed slaves. It is clear that in the first century of Islam, ${ }^{27}$ to join the movement was to join the Arab society. During the Arab conquests of the surrounding, non-Arab societies, some individuals and groups among the conquered peoples converted to the new faith and joined the ranks of the Arabs. Of those who did not convert immediately, many slaves were taken, some of whom were later manumitted on conversion. Both categories-immediate converts and freed slaves-became mawāli, and thus incorporated into the Arab society. ${ }^{28}$ In spite of the shared faith, however, the mawāli were regarded as second class citizens by the Arabs headed by the Umayyad rulers. Patricia Crone argued that their situation was much like the indigenous peoples in the European colonies in the nineteenth and twentieth centuries. She held that one way for the mawāti to assert their identity in the new society was to separate themselves from the Umayyad Arab chauvinist ideology. The main alternative open to them was to align with the Shi'ites, and adopt their reverence for the family of the Prophet which "formed a sacred lineage so greatly elevated above Arabs and non-Arabs alike that the differences between the two were drained of importance". ${ }^{29}$ At the same time, the mawāli could identify with the sufferings of the ahl al-bayt; both groups had been treated badly by the Umayyads and those affiliated with them. Thus, seeking vengeance for Husayn - the grandson of the Prophet who was killed by the Umayyads - was a very concrete way to break the ties with the Arab

26 For a discussion problematizing the concepts of Arabs and Arabic tribes in pre-Islamic times, see Webb, Imagining the Arabs, esp. pp. 39-42.

27 Donner ("Believers to Muslims"; Muhammad and the Believers) has argued (convincingly in my opinion), that the terms islām and muslim were not used as a name for a particular religious group and its adherents until the beginning of the seventh century CE. The designation used before that time was mu'minūn, "Believers".

28 Hoyland, In God's Path, pp. 157-169; but cf. Webb, Imagining the Arabs, pp. 242-244, and esp. p. 280, n. 18.

29 Crone, "Mawālē" p. 186. Although Urban ("Early Islamic Mawālı̄" pp. 86-98) expresses problems with Crone's and others' "ethnification" of the concept of mawlā, she accepts the view that the mawāli tried to create new and inclusive forms of nobility, based on Islamic virtue rather than birth and lineage. In her thesis, Urban views the phenomenon of the mawāli from quite a different and interesting perspective than many earlier historians. A problem, however, is her often uncritical use of single sources and isolated traditions as bases for her arguments. 
society in its present form, and try to shape something new. ${ }^{30}$ As the number of mawā $\bar{\imath}$ grew, it was increasingly difficult to uphold the system of tribal affiliation, and in the movement of al-Mukhtār they were regarded by many as a threat to the Arabs rather than as a part of society. ${ }^{31}$

To make a sharp distinction between Arabs and non-Arabs is, however, to oversimplify. There were plenty of mawālì who were loyal to their tribes in early Umayyad times, just as many Arabs loathed and fought against the Umayyads, and joined the Shi ite movement. ${ }^{32}$ As I have already mentioned, several sources indicate that the second major group that constituted al-Mukhtār's following were Arabs belonging to South Arabian tribes. ${ }^{33}$ The Southern Arabs seems to have been politically and religiously divided, the rifts between followers of and opponents to al-Mukhtār extending even within the tribes. The sources do not reveal the reasons why certain Southern groups or individuals joined his movement while others did not. ${ }^{34}$

As suggested above, one reason for al-Mukhtār's success in marshalling such large numbers was that he called the people to revenge for the blood of the family of the Prophet, in particular of Husayn. He was able to win over the Arab nobleman Ibrāhīm b. al-Ashtar (of the southern Arabian tribe Madhhij) by producing a letter that he alleged was written by the Mahdi, Ibn al-Hianafiyya. Ibn al-Ashtar became one of al-Mukhtār's most successful commanders, and the movement then managed to oust Ibn al-Zubayr's governor in Kufa. The chronology of the following events is unclear as the sources differ, but they all agree that al-Mukhtār and his movement took a harsh revenge on the Kufans who had taken part in the battle against Husayn. In 67/686, alMukhtār sent an army led by Ibn al-Ashtar against a great Umayyad force, and managed to defeat it and to kill 'Ubayd Allāh b. Ziyād at Nașībīn in Northern Iraq. Ibn Ziyād had been governor in Kufa when Husayn approached the town, and was responsible for his killing. Finally, a few months later, al-Mukhtār's movement was crushed by an army led by the governor of Basra, Mus'ab b. alZubayr, brother to 'Abd Allāh b. al-Zubayr. Kufa was regained, and al-Mukhtār was besieged in the palace of the town for some weeks before he was killed.

\footnotetext{
30 Crone, "Mawālē" pp. 184-186; Political Thought, pp. 84-85.

31 Urban, "Early Islamic Mawālē" pp. 98-104.

32 Crone, Political Thought, pp. 85-86.

33 Djaï, "Les Yamanites," pp. 168-170; Rotter, Bürgerkrieg, pp. 99-101.

34 Watt's hypothesis ("Shi'ism," pp. 161-162) that South Arabian ideas about a charismatic leader was behind their promotion of 'Alī and his descendants has not been supported by later studies, to my knowledge.
} 


\section{Sources for the Story of al-Mukhtār}

In the introduction to this article, I mentioned that the movement of alMukhtār is one of the most fully recorded in the early history of Islam. What I meant by this is that there are several sources that seem to be mutually independent that relate the story of the movement in full or in part, or that touch on or allude to details in it. In this section, I will give an overview over the sources used for the present study:

(1) Abū Mikhnaf (d. 157/774) gives the most comprehensive account by far. The original text is lost to us, but it is related by al-Tabarī (d. 310/923) $)^{35}$ who quite faithfully seems to have reproduced his "book" Kitāb al-Mukhtār $b$. $A b \bar{\imath}$ 'Ubayd, ${ }^{36}$ and in abbreviated forms by al-Balādhurī (d. 279/892) and Ibn A'tham. ${ }^{37}$ Al-Balādhurī's and Ibn A'tham's versions are much more edited than that of al-Tabarī, and I will not refer to them in the analysis. (Al-Balādhurī does have some material not found in al-Ṭabarī's version, but since it does not have any significance for the present study, I will not consider it.)

(2) Al-Dīnawarīs (d. around 290/902) account differs considerably from that of Abū Mikhnaf when it comes to wording and chronology, and thus seems to be independent of it. ${ }^{38}$ Fishbein argues that al-Dinawari drew some of his material from al-Wāqidī (d. 207/823) or his sources. ${ }^{39}$

(3) The parts of Ibn Sad's (d. 230/845) entry about Ibn al-Hanafiyya where anecdotes about the dealings between the latter and al-Mukhtār are

35 Al-Ṭabarī, Tārīkh, ser. II, pp. 599-746. In the following, I will normally refer only to the Leiden edition of al-Ṭabarīs Tārīkh. The English translation made by G. Hawting al-Ṭabarī, History, vol. XX., and M. Fishbein al-Tabarī, History, vol. XXI also give the pagination of the Leiden edition in the margin, and it should be easy for any reader to consult the English text even though it is not referred to directly. Only when the translation is quoted, I refer to it. Fishbein's thesis "Life of al-Mukhtār" to a large extent is a translation of the entire text of al-Ṭabarī about al-Mukhtār. It is useful for comparison with Hawting's translation.

36 This text is mentioned by Ibn al-Nadìm, Fihrist, p. 93; see also Sezgin, Abū Mihnaf, pp. 108109. I have put the word "book" within quotation marks in order to show that by this I do not mean a published book in the modern sense. For a discussion of the question of oral and written material, see Schoeler, The Oral and the Written, pp. 28-44.

37 Balādhurī, Ansāb, vol. v, pp. 207-208, 212-273; Ibn A'tham al-Kūfì, Futūh, vol. vi, pp. 53-58, 73-77, 87-200. The date of Ibn A'tham's death has been contested. Conrad, "Ibn A'tham," pp. 90-96 has suggested the beginning of the ninth century; Lindstedt, "Sources," however, has convincingly argued for the more traditional date a century later.

38 Al-Dīnawarī, $A k h b \bar{a} r$, vol. I, pp. 296-316. I will normally refer only to Guirgass' edition. Fishbein has translated this text ("Life of al-Mukhtār," pp. 462-495), and has included page numbers from this edition.

39 Fishbein, "Life of al-Mukhtār," pp. 15-16. 
interspersed, differ in some respects from that of al-Dīnawarī. Moreover, it is clearly a source which is independent from that of Abū Mikhnaf, and thus must be taken into consideration. ${ }^{40}$

(4) Al-Balādhurī and al-Ṭabarī introduce a short account which probably stems from the well-known Kufan traditionist 'Abd Allāh b. al-Mubārak (d. 181/797). ${ }^{41}$ As I have mentioned above, al-Balādhurī's version is abbreviated, so in this study I will only refer to al-Ṭabarì's rendering of Ibn al-Mubārak.

(5) The historical accounts are now and then interrupted by poetry ascribed to contemporary poets, i.e. to eye witnesses that have attempted to immortalise an event through a poem. If these poems are really written by the person to whom they are ascribed they are excellent, though limited sources to the events that they depict. ${ }^{42}$ The events studied here are illustrated by poems that are reproduced by two or more independent sources, and/or are written by famous authors that are named in the text. A poem may be forged, but it is less likely in the case of famous poets whose works were so well known that falsely attributed poetry would probably have been exposed. For that reason, I have used three poems which I have considered as genuine: one by 'Abd Allāh b. Hammām alSalūlī (d. after 96/715);43 one by A'shā Hamdān (d. 83/702);44 and a short poem by al-Mutawakkil al-Laythī (d. after $72 / 691) .{ }^{45}$

(6) A final source which is very valuable in spite of its limited scope of interest, is the Syriac chronicle Riš Mellē by the contemporary Christian writer John bar Penkāyē. It is probably written sometime between 687 and $691 \mathrm{CE}$, and contains a passage which confirms al-Mukhtār's revolt in Kufa, his following among the mawa $\bar{l} \bar{l}$, and the victorious battle at Nașībīn. ${ }^{46}$ I have used the translation by Brock. ${ }^{47}$

$40 \quad$ Ibn Sacd, Țabaqāt, vol. 5, pp. 72-78. Elsewhere, I have studied the relationship between Abū Mikhnaf and Ibn Sa'd's accounts about al-Mukhtār more in detail (Hylén, "Mukhtār and the Mahdī" pp. 145-148).

41 Balādhurī, Ansāb, vol. 5, p. 242; Ṭabarī, Tärīkh, ser. II, pp. 702-705.

42 Robinson, Islamic Historiography, p. 52.

43 Al-Ṭabarī, Tārīkh, ser. II, pp. 636-638; Dīnawarī, Akhbār, vol. I, p. 299. On al-Salūlī, see El-Achèche, ch. 4; Pellat, "Abd Allāh b. Hammām al-Salūlī".

Al-Ṭabarī, Tärīkh, ser. II, pp. 704-705. For a discussion of different versions of this poem given in other sources and an analysis of these, see Anthony, The Caliph, pp. 277-290.

45 Al-Ṭabarī, Tärīkh, ser. II, p. 705.

46 Hoyland, Seeing Islam, pp. 194-200.

47 Brock, "North Mesopotamia". 


\section{Al-Mukhtār's Authority}

As we have seen, by the time of al-Mukhtār, the myth ${ }^{48}$ of 'Alì was already quite developed. He was highly revered among Shicites in general, and, it seems, worshipped by some groups. The notion of $\operatorname{din}$ 'Ali, "the religion of 'Alī", was well-known and important to the believers. Al-Mukhtār's feat was to have found media with which to channel this reverence for 'Alī so that it became a means to support his own authority. To use concepts from Meyer's theory, these media bridged the distance between the transcendent 'Alī and his devotees; al-Mukhtār's control of the media and their "distribution" contributed to his authority. In the present study, three such media will be discussed:

(1) He claimed to act on behalf of one of 'Alī's sons, Muhammad b. alHanafiyya, and called the latter al-mahdī, "the rightly guided";

(2) He called to revenge for the death of 'Alì's son Husayn, and actually accomplished this;

(3) He produced "Alī's chair" (kursī Alī).

Other such media could probably have been chosen in addition to these. For example, al-Mukhtār's use of rhymed prose $\left(s a j^{\top}\right)$ —employed by pre-Islamic soothsayers to convey revelations from the spiritual world - might have been mentioned. ${ }^{49}$ Constraints of space oblige me to concentrate on the three media mentioned here, however. In this context I use the term "media" as an analytical tool, following Meyer. Al-Mukhtār did not, of course, use it himself. Furthermore, I do not intend to say that he cynically exploited the credulity of his followers for his own benefit. This may have been so, but in fact, contemporary or near-contemporary sources say very little about his motives, although later sources often describe him as "liar". ${ }^{0}$ As mentioned above, I will discuss the historicity of each of the media while accounting for it and analysing its function.

\section{Al-Mukhtār's Acting on Behalf of Muhammad b. al-Hanafiyya}

'Alī, then, was regarded the legatee (wașī) of the Prophet Muhammad. AlMukhtār claimed that, as the most prominent son of 'Alī still alive, Ibn alHanafiyya was now the rightful successor of the Prophet. According to Abū Mikhnaf and the poet 'Abd Allāh b. Hammām, al-Mukhtār called him the son

48 I define "myth" as a narrative that is foundational to the world view or identity of a group of people. For a discussion leading up to this definition, see Hylén, "Husayn, the Mediator," pp. 20-31.

49 Anthony, The Caliph, pp. 272-273, 287-289.

50 On this, see also Fishbein's comparison between the texts of Abū Mikhnaf and al-Dīnawarì regarding al-Mukhtār's motives in "Life of al-Mukhtār," pp. 46-51. 
of the legatee, ibn al-wași..51 By associating himself with Ibn al-Hanafiyya, alMukhtār used the position of the former as a way to defer to 'Alī himself, and thereby as a medium to promote his own authority. Two of the sources investigated here indicate that al-Mukhtār referred to himself as the wazir ("helper") of Ibn al-Hanafiyya: by Abū Mikhnaf in several places, ${ }^{52}$ and Ibn Hammām in a poem quoted by Abū Mikhnaf. ${ }^{53}$ This term is used twice in the Qur'ān to describe the relationship between Moses and Aaron, in which God makes Aaron the wazir , the helper or assistant of Moses. ${ }^{54}$ It is possible that al-Mukhtār by using it may have had the intention to establish a relationship between Ibn alHanafiyya and himself equal to that between Moses and Aaron. ${ }^{55}$

Al-Muktār furthermore talked of Ibn al-Ḥanafiyya as al-mahdī, "the rightly guided one". This concept and its use in the first century of Islam have been much studied by contemporary scholarship, in particular in connection with al-Mukhtār and his movement. ${ }^{56}$ Words created from the Arabic root $h-d-y$, here connoting divine guidance, occur frequently in the Qurān. Indeed, the concept is "as central to Islam as salvation is to Christianity". ${ }^{57}$ Although the passive participle mahdī, "rightly guided [by God]" does not occur in the Qurān, it was used very early in Islam. Most scholars are of the opinion that the term did not have messianic implications at the outset of Islam; it simply meant that the person described by this epithet-normally some kind of leader — was divinely guided. Many hold, that it was only when al-Mukhtār

51 Al-Ṭabarī, Tārīkh, ser. II, pp. 534, 611, 637. There is in fact one more instance of this expression on p. 747. In this case it is ascribed to Ibn al-Hanafiyya himself, who uses it in a letter that he allegedly wrote to al-Mukhtār. The letter is quoted in a tradition ascribed to a certain 'Alī b. Harb al-Mawsilī, a traditionist, historian, and poet who died in 879 CE. The tradition is quite short, however, and I have not found any other version of it, so it has not been possible for me to determine its historicity. For that reason I do not consider it probative in the present context.

See e.g. ibid., p. 534, 6o8, 611 .

53 Ibid., p. 638.

54 Qur'ān 20:29-34 and 25:35. Sunni as well as Shici tradition equal this relationship to that between the Prophet Muhammad and 'Alī. I have not been able to verify any occurrences of this tradition earlier than in Ibn Sa'd's al-Tabaqāt, referring back to al-Wāqidī Țabaqāt, vol. III, pt. 1, pp. 14 ff. However, there are many traditions about this in both Sunni and Shici hadìth collections and other sources (for references to Sunni hadìth collections, see Wensinck, Handbook, p. 15; for some Shi'ite sources, see Bar-Asher, Scripture and Exegesis, p. 156, n. 122,) so most probably it is much earlier, perhaps even going back to the lifetime of the Prophet and 'Alī. On this theme, see also Crone and Cook, Hagarism, pp. 26-28; Rubin, "Prophets," pp. 51-52.

55 Goitein, "Vizier”; Crone, Political Thought, pp. 77-78; Anthony, The Caliph, pp. 267-268.

$5^{6}$ The following section is abbreviated from Hylén, "Mukhtār and the Mahd".

57 Arjomand, “Apocalypticism," p. 250; see also Izutsu, Ethico-Religious Concepts, pp. 193-195. 
referred to Ibn al-Hanafiyya as al-mahdi that the term first came to mean a kind of messiah. ${ }^{58}$ There is in fact very little in the text that associates the term al-mahdi with any kind of messianism. I will return to this question shortly.

Most modern scholars maintain that al-Mukhtār used the epithet al-mahdī of Ibn al-Hanafiyya. ${ }^{59}$ Two independent sources state that al-Mukhtār referred to Muhammad b. al-Ḥanafiyya as al-mahdī: Abū Mikhnaf ${ }^{60}$ and Ibn Sacd. ${ }^{61}$ In addition to these sources there is also a poem by the contemporary Ibn Hammām, where other forms of the root are used referring to him. ${ }^{62}$ These three sources: Abū Mikhnaf, Ibn Sa'd, and 'Abdallāh b. Hammām taken together, in my opinion, make it most probable that al-Mukhtār and his companions actually referred to Ibn al-Hianafiyya as al-mahdi.

The next question, then, is what al-Mukhtār and his companions meant by this title. Despite views to the contrary by many scholars, there is in fact very little in the sources that indicates that Ibn al-Hanafiyya was regarded as a messianic redeemer. The only passage in the sources where al-Mukhtār purportedly uses phrases that could be interpreted in this direction is transmitted by Abū Mikhnaf, who relates al-Mukhtār's propaganda to win over the Tawwābün to his side before their disastrous journey:

I have come to you from the one who is in authority, the source of virtue, the legatee of the Legatee, and the Imām the mahdī, with an authority in which there is restoration of health, removal of the covering, fighting against the enemies, and fulfilment of favors ... Listen to what I say and obey my command, and then rejoice and spread the good news. ${ }^{63}$

Arjomand quotes parts of this passage, ${ }^{64}$ and, with him I italicise the phrases that he regards as having a particularly apocalyptic tinge. I agree with him that these clauses can, perhaps should, be interpreted from an apocalyptic

58 Arjomand, "Apocalypticism," p. 250; Donner, "La question du messianisme"; Donner, Muhammad and the Believers, pp. 184-185; Anthony, "Kaysāniya". For the view that the term al-mahdī had messianic connotations from the beginning, see Crone and Cook, Hagarism, pp. 3-6, and in less affirmative terms, Crone, Political Thought, p. 75. Crone and Hinds, however, state that al-Mukhtār probably was the first to use the term, referring to Ibn al-Hanafiyya, "in the sense of a specific and long-awaited redeemer figure", God's Caliph, p. 103 .

59 For a thorough analysis, see Hylén, "Mukhtār and the Mahdī," pp. 145-150.

6o Al-Ṭabarī, Tärīkh, ser. II, pp. 509, 533-534, 608, 610-611, 620, 674-675, 694.

61 Ibn Sacd, Țabaqāt, vol. 5, pp. 72-74.

62 Al-Ṭabarī, Tärīkh, ser. II, p. 638; History, vol. XX, p. 222.

63 Al-Ṭabarī, Tārīkh, ser. II, p. 534; History, vol. XX, p. 120.

64 Arjomand, "Apocalypticism," p. 250. 
perspective, but as already mentioned, they are the only statements which describe the mahdi and the mission he has given to al-Mukhtār in such terms. Thus, it cannot be established that al-Mukhtār actually uttered these words, or something similar.

In addition to this single passage, there is a curious incident related by Ibn Sa'd, in which al-Mukhtār ascribes supernatural (although not necessarily messianic) qualities to Ibn al-Hanafiyya as al-mahdī. We are told that in Mecca, Ibn al-Hanafiyya was harassed by Ibn al-Zubayr, who wanted a pledge of allegiance from him. Ibn al-Hanafiyya considered leaving the hostile situation and going to the more friendly Kufa. Al-Mukhtār heard about this but did not like it:

[Ibn al-Ḥanafiyya's] coming was bothersome for [al-Mukhtār], and he said: "In al-mahdì there is a sign ['aläma]. He will come to this town of yours [i.e. Kufa] and in the market place a man will strike him with a sword, but it will not harm him or make a mark on him." Ibn al-Hanafiyya came to know about this and he stayed [where he was]. ${ }^{65}$

According to this passage, al-Mukhtār spread the word that Ibn al-Hanafiyya was invulnerable and that this was a sign of his being al-mahdī. But, he also prophesied that someone would test this if Ibn al-Hanafiyya came to Kufa. In this way al-Mukhtār frightened Ibn al-Hanafiyya from coming and putting his life on trial. As related by Ibn Sa'd, the incident is thus a ruse of al-Mukhtār to keep Ibn al-Hanafiyya at arm's length. Should it be accepted as historical, it would show that the idea of a Mahdi with superhuman qualities was not alien to al-Mukhtār and his followers. ${ }^{66}$

These two isolated traditions are the only overt examples in the sources of any kind of messianic or superhuman traits attributed to Ibn al-Hanafiyya by al-Mukhtār. The fact that they relate two separate events in different contexts, in my opinion makes it impossible to verify their historicity. Thus, I do not think that there is textual evidence enough to prove that it was al-Mukhtār who first associated the term al-mahdi with different messianic ideas. It seems evident, however, that this connection was made by the movement that evolved after his death, the Kaysāniyya, in the last decades of the first/seventh century.

65 Ibn Sa'd, Tabaqāt, vol. 5, p. 74, my translation.

66 It seems that to Qadi (Al-Kaysānīya, p. 124) this was an episode that actually occurred. In fact, it is the only incident she refers to as an argument for al-Mukhtār's promotion of Ibn al-Hanafiyya to a super-human level. Dixon (Umayyad Caliphate, p. 58) and Anthony (The Caliph, pp. 259-26o) seem to leave the question of its historicity open (but cf. Anthony, "Kaysāniya"). 
As we have seen above, it was first and foremost 'Alī with whom messianic traits were associated, and this will be further corroborated in the analysis of the incident of the chair of 'Alì that follows. The notion of al-mahdī, on the other hand, is confined to Ibn al-Hanafiyya in the story of al-Mukhtār. It has been argued that 'Alī had indeed been called al-mahdī (albeit in a non-messianic sense) previous to al-Mukhtār and his movement. ${ }^{67}$ Supposedly, this occurred when Sulaymān b. Surad, the leader of the Penitents movement, during the visit at Husayn's grave called the latter "the right-guided one, son of the right-guided one" (al-mahdī ibn al-mahdī). ${ }^{68}$ This argument, however, confuses the event of the Penitents, which as we have seen occurred just before the rebellion of al-Mukhtār, with the account given of the movement, which cannot be dated with any kind of security before the beginning of the seventh century, i.e. a couple of decades after al-Mukhtār. ${ }^{69}$ Hence, this text can hardly be used as an argument that 'Ali was viewed as the Mahdi before the time of al-Mukhtār, either in a non-messianic or a messianic sense.

However, that Ibn al-Hanafiyya was rightly guided ("mahd $\vec{\imath})$ was in the mind of al-Mukhtār and the Shicites in Kufa of course an effect of him being the legatee of 'Alī, who in his turn was the legatee of the Prophet Muhammad. Although it cannot be established that al-Mukhtār filled the concept of almahdi with a messianic content himself, he certainly paved the way for such a synthesis after his death. More important for the present study is that he deferred to 'Alì by making himself the wazir of the "son of the legatee". Thus, he used Ibn al-Hanafiyya as a medium, in Meyer's sense, between 'Alī and the Shi'ites, to support his own authority. By producing letters from Ibn alHanafiyya (whether forged or not), al-Mukhtār buttressed his claim to have been sent by the former. It seems, however, that this platform was not as robust as he would have wished. Ibn al-Hanafiyya himself was cautious about being associated with al-Mukhtār, and at least initially some of the Shicites doubted that the latter was sent by 'Alì's son.

\section{Al-Mukhtār's Revenge for the Death of Husayn b. 'Alī}

So many independent sources relate that al-Mukhtār gained influence by summoning people to seek revenge for the killing of Husayn b. 'Alī, and actually killed most of the leadership of the campaign against Husayn, that it can

67 E.g. Sachedina, Islamic Messianism, p. 9; Fishbein in Țabarī, History, vol. XX, pp. 40, n. 160; Anthony, "Kaysāniya".

68 Țabarī, Tārīkh, ser. II, p. 546.

69 Moreover, on grammatical and structural grounds, I suspect that this sentence is a later insertion to the text. I plan to present my arguments for this in more detail in a coming publication. 
be regarded as an established historical fact. It is normally expressed as vengeance "for the blood of Husayn" or "for the blood of the Prophet's family" or something similar in the sources. Thus, al-Tabari transmits material about this from Abū Mikhnaf, ${ }^{70}$ from the poet 'Abd Allāh b. Hammām al-Salūlī (via Abū Mikhnaf) ${ }^{71}$ and from 'Abd Allāh b. al-Mubārak. ${ }^{72}$ The same kind of expression is found in Ibn Sa'd and al-Dīnawarī. ${ }^{73}$ The sources also relate how al-Mukhtār and his companions actually achieved revenge by seeking out and killing men that were involved in the battle of Karbalä' on the Umayyad side, including 'Umar b. Sa'd and other leaders of the Karbalä' campaign living in Kufa. The victorious battle against the person ultimately responsible for the killing of Husayn, 'Ubayd Allāh b. Ziyād, is mentioned also by the Christian John bar Penkāyē. Although the latter does not mention revenge for Husayn as motive for the Kufan troops (he rather adduces political and economic motives for the rebellion of al-Mukhtār), he confirms the battle at Nașībīn and its outcome. ${ }^{74}$

The story about the Penitents movement shows that seeking revenge for the killing of Husayn was a crucial matter for the Shicites in Kufa. Although the main elements of this story as presented by al-Tabarī (through Abū Mikhnaf) cannot be established before the beginning of the second/eighth century, ${ }^{75}$ it would be very difficult to explain it without taking account of a real feeling of guilt of the members in the group, and that this feeling was prevalent among many of the Kufan Shi ites. To be true, one must take into consideration the fact that the numbers of the Penitents are most probably exaggerated in the story, at least the amount of those who declared their loyalty but never showed up at the actual campaign (16,ooo men according to Abu Mikhnaf). ${ }^{76}$ Still, the movement must have had a considerable impact on the Shi ites of the town, and reflected the feelings of many of them. Thus, it is not surprising that al-Mukhtār succeeded in rising support for himself as a leader with an alleged mission from Husayn's half-brother to wreak the vengeance which the Penitents had failed to exact for Husayn's death. The revenge would have caused a relief from the guilt felt towards the family of 'Alī, thereby restoring the lost honour of those who had failed to support 'Alì's son at Karbalā'. Associating to Meyer's theory, the revenge for Husayn thus functioned as a medium which strengthened the link between 'Alī and his devotees.

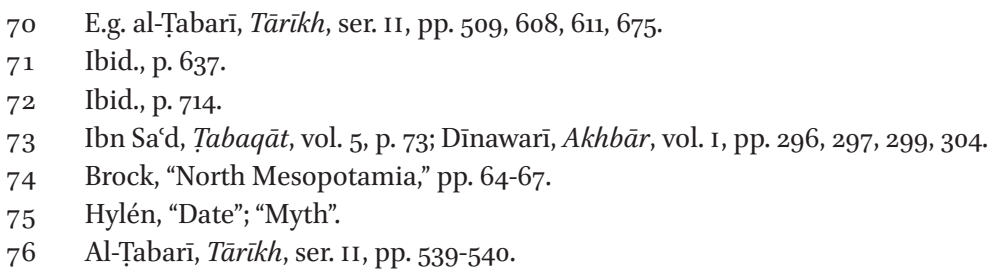




\section{Al-Mukhtār and 'Alï's Chair}

Several sources relate that, before embarking on the campaign against the Syrians, al-Mukhtār presented a chair (kursī) which he claimed had belonged to 'Alī. ${ }^{77}$ This chair aroused great enthusiasm among some of the followers of al-Mukhtār. The curious affair of the chair is dealt with by several of the sources mentioned above: two narratives by Abū Mikhnaf and 'Abd Allāh b. al-Mubārak respectively, and two hostile poems by A'shā Hamdān and alMutawakkil al-Laythī. All are reported by al-Ṭabarī, and in the following I will mainly rely on his account. ${ }^{78}$ However, Anthony relates a longer rendering of A'shā's poem, ${ }^{79}$ taken from al-Jāḥiz's Kitāb al-Hayawān, and when needed I will also consider this version as it is presented by Anthony.

Why did a chair that had belonged to 'Alī create such excitement? What did the chair represent in the life of 'Alī, and what function could it have had for him? Two hypotheses are presented regarding this. The first, suggested by Shaul Shaked, ${ }^{80}$ argues that the chair of 'Alì was a replica of an Iranian symbol of power: the royal throne, which symbolised legitimate power and carried with it sacred associations. The second theory is advanced by Sean Anthony, who, against Shaked, maintains that "a more plausible explanation is that the chair was revered because 'Alī had sat upon a chair while commanding his armies, a common practice for Arab commanders in the early Islamic period". 81 Although both hypotheses are conceivable (and perhaps not mutually exclusive) none of them can be verified by the sources.

Two versions of how the chair was introduced to al-Muktār's followers are extant. According to the version of Ibn al-Mubārak, Țufayl b. Ja'da b. Hubayra - a grandson of Umm Hāni' a sister of 'Al̄̄ — was once in need of money. He went to his neighbour, an oil merchant, who had a dirty old chair. Tufayl took the chair, cleaned it and sold it to al-Mukhtār for a large sum as being the chair of 'Alī. ${ }^{82}$ According to the other version, related by Abū Mikhnaf, it was alMukhtār who took the initiative and nagged the relatives of Umm Hāni' to give him 'Alī's chair. They denied that they had it, but finally, to make an end to his pestering, the family gave al-Mukhtār a chair and said that it had been

\footnotetext{
77 In the following section, I am deeply indebted to the comprehensive analysis that Sean Anthony (The Caliph, pp. 261-29o) has made of the different accounts of the chair and its significance.

78 Tabarī, Tārīkh, ser. II, pp. 701-706.

79 Anthony, The Caliph, pp. 278-279.

8 o Shaked, "From Iran to Islam," pp. 79-82.

81 The Caliph, p. 268, n. 82.

82 Al-Ṭabarī, Tārīkh, ser. II, pp. 702-703.
} 
'Alì's chair. ${ }^{83}$ None of these accounts can be verified, and both give the impression of having been contrived to portray al-Mukhtār in an unfavourable light. ${ }^{84}$

More interesting than the stories about its origin is the way the chair was received by al-Mukhtār's followers and the ideas associated with it. The sources relate that it immediately became a kind of cultic object to some of the followers of al-Mukthār, who regarded it on a par with the Israelite Ark of the Covenant. It was covered with silk and brocade, and the people raised their hands, circled around it, ${ }^{85}$ and shouted. Attendants were appointed to it, and it was placed on a grey mule and brought out in the battle of Nașībīn against the Umayyad army as a kind of talisman — a battle that, as we have seen, was very successful.

The allusion to the Ark of the Covenant is consistent with al-Mukhtār's attempt to depict himself as the representative of Ibn al-Hanafiyya. Although it is nowhere reported that al-Mukhtār states that the chair of 'Alī is the Ark of the Covenant, one source relates him as saying: "Among the children of Israel there was the Ark, in which there was a remnant of what the family of Moses and the family of Aaron left behind. Among us, this is like the Ark." ${ }^{\prime 86}$ The Ark of the Covenant is important in Islamic tradition. ${ }^{87}$ It is mentioned only once in the Qur'ān, in an account where the people of Israel has asked their prophet (i.e. Samuel) to give them a king. He replies that God has chosen Țâlūt (i.e. Saul) as their king, but they do not want him. The prophet then says:

Surely the sign of his kingship is that the ark will come to you. In it is Sakina from your Lord, and a remnant of what the house of Moses and the house of Aaron left behind. The angels (will) carry it. Surely in that is a sign for you, if you are believers. ${ }^{88}$

83 Ibid., p. 705-706.

84 Anthony, The Caliph, p. 265.

85 The word țâfa, used to denote the circling around Ka ${ }^{\mathrm{c}} \mathrm{ba}$, is used only in the disapproving poem by A'shā Hamdān (see e.g. Balādhurī, Ansāb, vol. v, p. 242., and al-Jāhiz's rendering of this poem in Anthony, The Caliph, pp. 278-279, esp. verse 6). Al-Ṭabarī (Tārïkh, ser. II, pp. 704-705) has not included this verse in his version of A'shā's poem. Abū Mikhnaf instead uses the word 'akafü (Ṭabarī, Tārīkh, ser. II, p. 702), and al-Mutawakkil derogatively says that they go "leaping around its boards" (ibid., p. 705).

86 Al-Ṭabarī, Tārīkh, ser. II, p. 703; History, vol. XXI, p. 7o. See also the poem by A'shā Hamdān in the version given by al-Ṭabarī al-Ṭabarī, Tārīkh, ser. II, pp. 704-705. The verse where the Ark is mentioned differs in al-Jāhiz' version of the poem Anthony, The Caliph, p. 278, n. 122.

87 Rubin, "Traditions".

88 Qurān 2:248, Droge's translation. In the Biblical version of this story (1 Sam. 8-10), the ark is not mentioned. 
Thus, in the Qur'àn the Ark has the function of legitimising authority. ${ }^{89} \mathrm{Al}-$ Mukhtār's association of the chair of 'Alī with the Ark of the covenant further strengthened his authority by creating the kind of link between himself and Ibn al-Hanafiyya that according to tradition had first existed between Moses and Aaron, a relationship that, as we have seen, was mirrored in the relation between the Prophet Muhammad and 'Alī. ${ }^{90}$ Anthony furthermore points to the widespread idea about the return of the Ark at the end of time. It had mysteriously disappeared during the Babylonian destruction of the Jerusalem Temple in $587 \mathrm{BC}$, and according to Jewish and Christian apocalyptic lore God would bring it back as a sign of the end times. ${ }^{91}$ Indeed, the words "a remnant of what the house of Moses and the house of Aaron left behind" in the verse quoted, most probably included the staff of Moses, which was closely associated with the Ark. As we have seen, this staff was a messianic insignia to be carried by 'Alī in the final battle against the evil powers of the world.

Another significant concept in the Qur'annic verse quoted is the presence of God expressed through the word sakina. It is cognate to the Hebrew/Aramaic word shekhina $/ s^{e} h^{e} h \bar{n} t \bar{a}$, and occurs several times in the Qur'ān. There it always

denotes divine aid and proof of the authenticity of God's agent in the face of disbelief and adversity, and this aid or proof (or divine presence) comes in the form of divine victory in battle or its potentiality. ${ }^{92}$

The word sakina is used by only one of the sources, the highly polemical poem by A'shā Hamdān. ${ }^{93}$ However, since the notion of the Ark of the Covenant is so intimately connected with the idea of God's presence-often expressed as His sakina - it is not unlikely that the chair of 'Alì was also seen as a container or recipient of God's sakina by the followers of al-Mukhtār. ${ }^{94}$

Moreover, it seems that the chair was regarded as some kind of medium for divine revelation in that it inspired prophecy (wahy). The poet al-Mutawakkil and one of Abū Mikhnaf's sources directly ascribe this idea to those that believed in the chair. ${ }^{95}$ And in distancing himself from them by claiming that he has followed the revelation (wahy) contained in the books, A'shā Hamdān in

\footnotetext{
89 Rubin, “Traditions," p. 200.

$90 \quad$ Ibid., p. 209-210; Anthony, The Caliph, pp. 267-268.

91 Anthony, The Caliph, pp. 273-275.

92 Firestone, "Shekhinah," p. 590.

93 Al-Ṭabarī, Tärīkh, ser. II, p. 704.

94 Rubin discusses the sakina as an expression of the presence of God Rubin, "Traditions," p. 200.

95 Al-Ṭabarī, Tārīkh, ser. II, pp. 705-706.
} 
his poem indirectly confirms that the idea of revelation associated with the chair prevailed among them. ${ }^{96}$

All this made many of al-Mukhtār's followers filled with enthusiasm over the "discovery" of the chair. At the same time, there were those who warned against the danger of falling into disbelief and committing polytheism. As far as we can tell, the chair was rather short-lived, and after the battle of Nașībin we hear no more about it. Both Abū Mikhnaf and Ibn al-Mubārak relate that the chair and the enthusiasm raised by it were severely criticised, and the two poems by A'shā Hamdān and al-Mutawakkil were outright hostile to it. ${ }^{97}$ The fact that the whole affair was passed over in silence by most later authors, notably by a Shicite like Ibn A'tham who certainly had recourse to Abū Mikhnaf's account, indicates that it was viewed by them as an embarrassment. This, in my opinion, is a strong argument in favour of its authenticity, as it could hardly have been invented by later generations.

In summary, the chair of 'Ali was an important medium between the more enthusiastic Shicites and 'Alī. Whether al-Mukhtār himself believed in its provenance we cannot know. It was a creative accomplishment which brought together, among other things, elements from the Quran and contemporary apocalyptic ideas. ${ }^{98}$

\section{Al-Mukhtār and the Aesthetics of Persuasion}

So far, I have described the three media used by al-Mukhtār to establish and support his authority—associating with a living and present son of 'Alī and identifying him as the Mahdi, exacting revenge for the killing of another of 'Alì's sons, and producing the chair of 'Alī - and argued that they probably have a historical basis. Applying Birgit Meyer's terminology, I have also in each case indicated how it could have functioned as a bridge between the Shi ites of Kufa and 'Alī, who was depicted as transcendent in one way or another. I will now return to theory to see if it can help wringing more information from the data available, as Fredriksen put it.

In the preceding pages, we have seen that the three media used by alMukhtār gave rise to much excitement among many of his followers. The significance of emotions in all kinds of religious performance and the expression and manipulation of these for political purposes have been highlighted in a

96 Ibid., p. 705 .

97 Ibid., pp. 702-706.

98 Anthony, The Caliph, p. 276. 
number of recent studies that use the concept of religious aesthetics as a theoretical framework, in particular those by Meyer. To repeat, Meyer holds that religion mediates between the temporal and the perceived divine. Thus media should not be regarded as something foreign to religion. She writes:

Once religion is understood as a practice of mediation, media-in the broadest sense: images, spirit mediums, written texts, sound, filmsappear not as Fremdkörper to religion, but as an inalienable condition on which any attempt to access and render present the divine and to communicate among religious practitioners ultimately depends. ${ }^{99}$

Media, understood in this broad sense, are thus essential to sensational experiences of the transcendent realm. Meyer regards media in religious contexts as active meditators that shape the religious experience rather than simply conveying it. She has coined the concept "sensational forms" for more institutionalised phenomena that act as mediators between the human and the perceived transcendental realm. Such forms are "authorized modes for invoking and organizing access to the transcendental that shape both religious content ... and norms". ${ }^{100}$ The term "form" is not thought of in opposition to the content of a religious tradition, but as a necessary condition for expressing it. ${ }^{101}$ Form furthermore allows religious experience to be repeated:

Though they are felt individually, religious sensations are socially produced, and their stereotyped repetition depends on the existence of formalized, authorized practices that frame individual religious sensations and enable their reproducibility. ${ }^{102}$

Thus, she argues, the person who is in control of the sensational form - whether it is an artefact, a rhetorical pattern, a perceived inner authority in a person, or something else-also has the power to distribute the religious sensations at his/her discretion. Meyer uses the expression "aesthetics of persuasion" to describe such a practice of power, and she illustrates this idea with examples from her research among Pentecostals in Ghana. ${ }^{103}$ I will point to another contemporary example, more in line with the present study, given by Vernon

99 Meyer, "Religious Revelation," p. 435.

100 Meyer, "Aesthetics of Persuasion," p. 751.

101 Ibid., pp. 750-751; Meyer, "Mediating," p. 1037.

102 Meyer, "Aesthetics of Persuasion," p. 754.

103 Ibid., pp. $75^{0-75^{8}}$. 
Schubel in his study of Shicite ritual in Pakistan. ${ }^{104}$ He there describes a majlis, a weekly gathering, which took place in Karachi for the remembrance and mourning of the death of Husayn b. 'Alī. He relates how the speaker (zākir) on the pulpit (minbar) starts with a formal sermon (khutba), and then gradually, as his sermon becomes more lively and emotional, animates the audience, who responds by shouting "Ya 'Alī!" Then he begins relating the story of the death of Husayn and his family at Karbalā', which everyone in the audience have heard many times.

At the first mention of the field of Karbalā', some of the men in the audience begin to cry uncontrollably and beat their chests. The sound of women's voices wailing can be heard rising up from the other side of the curtain which divides the room. ${ }^{105}$

As the story proceeds, the narrator changes from past to present tense, and after a while the whole room is filled with grief. The narrator himself "collapses in tears before his audience". Schubel continues:

As the performance ends and the crowd collects itself, those who have come to mourn the sufferings of the martyrs of Karbalā' have reaffirmed their loyalty and devotion to them ... To the extent to which the man on the minbar — the $z \bar{a} k i r$ - was able to elicit tears and impart information, he has succeeded in his task. ${ }^{106}$

Although Schubel does not particularly analyse the role of the zākirs in Pakistani Shicism from a perspective of power, he touches upon it here and there, and demonstrates the importance of their sermons in the creation of a sense of community among Shicites in the country. ${ }^{107}$ In the terminology of Meyer, religious functionaries like Pentecostal pastors and Shi ite $z \bar{a} k i r s$ create channels or bridges between the human beings and the supernatural. By reiterating certain sensational forms — for example the majlis ritual—-they can re-create particular religious sensations, and at the same time exclude others. ${ }^{108}$ Their power is thus based on an ability and authority to create and reject religious sensations, or in other words, to distribute them.

\footnotetext{
104 Schubel, Religious Performance, pp. 11-12.

105 Ibid., p. 12 .

106 Ibid.

107 Ibid., p. 72-74, 90-106. Schubel analyses Shi'ite performances in Pakistan using the anthropologist Victor Turner's theoretical framework as a toolbox.

108 Meyer, "Aesthetics of Persuasion," p. 755.
} 
My argument in the present study is that al-Mukhtār to a great extent accomplished his political endeavour by controlling the three media between the people and 'Ali that I have analysed above. These media, I hold, were successful in that they met the expectations of his followers, and in that they related to their previous experiences, religious and political. However, I am hesitant to use Meyer's concept of sensational forms to describe al-Mukhtār's moves to appeal to the people around him. When she defines and explains her concept of sensational forms, she applies it to regular or recurring rituals and religious events, such as weekly services and annual festivities. It is in these situations that the religious functionary has the power to create and recreate religious sensations. In the case of al-Mukhtār, however, none of this regularity is found. The three media were not that developed. According to Meyer, sensational forms gradually emerge in history; they are "historically generated"; they "emerge over time and are often subject to contestation and even abandonment.... They are thus an excellent point of entry into processes of religious transformation". 109 As I interpret Meyer on this point, repetitive patterns are not extant from the beginning. When a religious movement emerges or changes, different forms of religious aesthetics are as it were tested; some disappear and others crystallise into set, authorised forms of which a few develop into what Meyer calls "sensational forms".

So, al-Mukhtār did not have recourse to sensational forms as described by Meyer, since the media he used had not yet developed to that extent. However, he did involve his followers in "particular practices of worship and patterns of feeling".110 These practices and patterns functioned as concrete mediators between those men and women who took them seriously and the transcendent realm to which 'Ali belonged. It is of course difficult to fully understand why the three media were successful but I will indicate two factors that I think can be identified without reading too much into the texts.

Reading Meyer's description of sensational forms, it seems to me that a precondition for success in creating particular religious sensations is the expectations of the adherents; the believers assume that these precise sensations will appear through a particular sensational form. Such expectations intensify over time when a pattern is repeated and brings with it the same kind of sensation. Consider the example of the majlis in Karachi that I related above, an example of a fully developed sensational form. The audience had heard the story of Karbalā' innumerable times; they had participated in many majālis before, and they knew what would happen. Once the $z \bar{a} k i r$ had succeeded in

\footnotetext{
109 Ibid., p. 751.

110 Ibid.
} 
building up the right atmosphere, only a small trigger, the mention of the word Karbalā', was needed in order to make some of the participants break into sobbing. Expectations about religious sensations that follow from a particular form are not the only precondition, however. The functionary also has to be able to relate to the experiences of the audience. Schubel relates a rather amusing incident about a Shiite $z \bar{a} k i r$ who visited an area in North Western Pakistan where tobacco chewing was prevalent. The zākir did not manage to bring his message home to his audience. No one cried, although he mentioned the hunger and thirst of Husayn and his family. It was not until he realised that it was because he did not relate to their own experiences that he was not able to catch the imagination of the listeners. Only when he mentioned that Husayn and his followers had had no tobacco to chew for three days, the crowd burst out in uncontrollable weeping. ${ }^{111}$

Returning to the story of al-Mukhtār, we have seen that messianic expectations were widespread in seventh-century Kufa, often directed towards 'Alī b. Abī Taàlib. Although such ideas were undoubtedly differently formulated by various groups within the amorphous movement that was called the Shicites, the general idea was that 'Alì's claim to authority as religious and political leader had been transmitted to his descendants. Furthermore, the experiences of deprivation and oppression on the part of some groups, notably the mawāli, seem to have facilitated their identification with the sufferings of 'Alī and his family. Thus, al-Mukhtār was able to provide forms of religious aesthetics that were accessible to his followers: an individual (Ibn al-Hanafiyya, son of 'Alī, legatee of the Prophet, and Mahdi), an action (taking revenge for the death of Husayn, the son of 'Alī), and an artefact (the chair of 'Alī). The three media thus functioned as bridges between the people and 'Alī. Although this factor alone cannot explain the authority of the people and the success of his followers, it needs to be taken into consideration in the analysis of his movement.

Going one step further, I argue that what we see in the accounts of alMukhtār is an early phase of a religious movement, the aesthetics of which has not yet crystallised into authorised forms. Some parts of those aesthetics would never do so. Of the three media that were used by al-Mukhtār to gain and sustain authority, one, the chair of 'Alī, subsequently completely disappeared. Another, the revenge for the blood of Husayn, was later translated both into an important element in Shicite ideology—the martyrdom ideal that has been

111 Schubel, Religious Performance, p. 106. Although illustrative for my argument, I cannot confirm this incident. Schubel relates it second hand, and it occurs to me that it could well be a kind of ethnic joke told among Shi'ites in Pakistan. 
interpreted in different ways throughout Shicite history —and a set of rituals, the most famous of which is perhaps the 'Āshūrä' celebrations. ${ }^{112}$ In this case we see how the early aesthetic form which al-Mukhtār promotes develops over the centuries into genuine sensational forms in Meyer's sense. An example is of course the majlis in Karachi related above. These forms are the subject for disputes and discussions, both when it comes to their performances and interpretations. ${ }^{113}$ Of course it is impossible to know how this aspect of Shicism had developed without the intervention of al-Mukhtār. The death of Husayn was already immensely important before al-Mukhtār's activity; what he did was to channel it into action, something which the Penitents had already tried to do. It is possible that the whole complex of ideas and rituals around the Karbalä' tragedy would have developed anyway. The third medium, however-the designation of a living son of 'Alī as the Mahdi who was the true leader in religious and political matters - was perhaps the invention of al-Mukthār that has had most significant repercussions in the following centuries. Although it cannot be demonstrated that it was with him that this concept got its messianic connotations, I do agree with many scholars who believe that al-Mukthār was instrumental in making the concept of the Mahdi popular. It is evident that in the movement that developed after him, the Kaysāniyya, this association between Mahdi and Messiah was an important feature. ${ }^{114}$ Furthermore, as far as we know, no one before al-Mukhtār had claimed to be acting on behalf of 'Alī or any of his sons, something which later became the rule. Anthony argues that

titling himself wazìr al-Mahdī, Mokttār established an oft-repeated precedent by acting as the imam's proxy in the political arena and accommodating, if not encouraging, an entirely passive role for Ebn al-Hanafiya. ${ }^{115}$

To conclude, al-Mukthār was able to channel the needs and aspirations of many of the Kufans by providing them with media, some of which subsequently developed into more formalised sensational forms. In so doing, he was also able to establish new patterns of authority, which later developed and became prevalent within the different strands of Shicism that we know today.

\footnotetext{
112 Much has been written about both of these. See e.g. Aghaie, Martyrs of Karbala; Halm, Shi'a Islam; Schubel, Religious Performance.

113 See e.g. Ende, "Flagellations"; Aghaie, Martyrs of Karbala.

114 Anthony, "Kaysāniya"; Qadi, Al-Kaysānīya, pp. 235-238.

115 Anthony, "Kaysāniya".
} 


\section{Bibliography}

Aghaie, Kamran Scot, The Martyrs of Karbala: Shi i Symbols and Rituals in Modern Iran, Seattle: University of Washington Press, 2004.

Amir-Moezzi, Mohammad Ali, "Muhammad le paraclet et 'Alī le messie: Nouvelles remarques sur les origines de l'islam et de l'imamologie shicite," L'Ésoterisme shi'ite, ses racines et ses prolongements = Shi i esotericism: its roots and developments, ed. Mohammad Ali Amir-Moezzi, Maria De Cillis, Daniel De Smet and Orkhan MirKasimov, Turnhout: Brepols, 2016, pp. 19-54.

Amir-Moezzi, Mohammad Ali, "Raj‘a," Encyclopedia Iranica, online edition, 2005, http://www.iranicaonline.org/articles/raja, (accessed Sept. 13, 2018).

Amir-Moezzi, Mohammad Ali, "Reflections on the Expression din Alī: The Origins of the Shi'i Faith," The Study of Shici Islam: History, Theology and Law, ed. Farhad Daftary and Gurdofarid Miskinzoda, London: I.B. Tauris, 2014, pp. 17-46.

Anthony, Sean W., The Caliph and the Heretic: Ibn Saba' and the Origins of Shi'ism, Leiden: Brill, 2012.

Anthony, Sean W., "Kaysāniya," Encyclopaedia Iranica, online edition, 2013 http://www .iranicaonline.org/articles/kaysaniya, (accessed Sept. 17, 2018).

Arjomand, Saïd Amir, "Islamic Apocalypticism in the Classic Period," The Encyclopedia of Apocalypticism, eds. Bernard McGinn, John Joseph Collins and Stephen J. Stein, New York: Continuum, 1998, pp. 238-283.

al-Balādhurī, Aḥmad b. Yaḥyā, Ansāb al-Ashrāf, vol. v, ed. S.D. Goitein, Jerusalem: Hebrew University, 1936.

Bar-Asher, Meir, Scripture and Exegesis in Early Imāmı̄ Shiism, Leiden: Brill, 1999.

Borrut, Antoine, "Remembering Karbalā': The Construction of an Early Islamic Site of Memory," Jerusalem Studies in Arabic and Islam 42 (2015), pp. 249-282.

Brock, Sebastian P., "North Mesopotamia in the Late Seventh Century: Book XV of Johna Bar Penkāyē's Rǐs Mellē," Jerusalem Studies in Arabic and Islam 9 (1987), pp. $5^{1-75}$.

Calmard, Jean, "Le culte de l'Imām Ḥusayn: Etude sur la commémoration du Drame de Karbalā dans l'Iran pré-safavide.” Ph.D. thesis, University of Paris III: EHEss, 1975.

Cameron, Averil, "Late Antique Apocalyptic: A Context for the Qur’an?" Apocalypticism and Eschatology in Late Antiquity. Encounters in the Abrahamic Religions, 6th-8th Centuries, ed. Hagit Amirav, Emmanouela Grypeou and Guy Stroumsa, Leuven: Peeters, 2017, pp. 1-19.

Conrad, Lawrence I., "Ibn A'tham and His History," Al-'Ușūr al-Wusțā: The Journal of Middle East Medievalists 23 (2015), pp. 87-125.

Crone, Patricia, "Mawāl̄ and the Prophet's Family: An Early Shī'ite View," Patronate and Patronage in Early and Classical Islam, ed. Monique Bernards and John Nawas, Leiden: Brill, 2005, pp. 167-194. 
Crone, Patricia, Medieval Islamic Political Thought, Edinburgh: Edinburgh University Press, 2004.

Crone, Patricia, and Michael Cook, Hagarism: The Making of the Islamic World, Cambridge: Cambridge University Press, 1977.

Crone, Patricia, and Martin Hinds, God's Caliph: Religious Authority in the first Centuries of Islam, Cambridge: Cambridge University Press, 1986.

Dakake, Maria Massi, The Charismatic Community: Shi'ite Identity in Early Islam, New York, NY: sunY Press, 2007.

al-Dīnawarī, Abū Ḥanīfa, al-Akhbār al-Ṭiwāl, ed. Vladimir Guirgass and Ignace Kratchkovsky, Leiden: Brill, 1888-1912.

Dixon, Abd al-Ameer Abd, The Umayyad Caliphate, 65-86/684-705: (A Political Study), London: Luzac, 1971.

Djaït, Hichem, "Les Yamanites à Kūfa au I ${ }^{e r}$ siècle de l'Hégire," Journal of the Economic and Social History of the Orient 19 (1976), pp. 148-181.

Donner, Fred M., "From Believers to Muslims: Confessional Self-Identity in the Early Islamic Community," Al-Abhath: Journal of the Center for Arab and Middle East Studies, Faculty of Arts and Sciences, American University of Beirut 50-51 (2003), pp. 9-53.

Donner, Fred M., "La question du messianisme dans l'islam primitif," Revue des mondes musulmans et de la Méditerranée 91-94 (2000), pp.17-28.

Donner, Fred M., Muhammad and the Believers at the Origins of Islam, Cambridge, MA: Belknap Press of Harvard University Press, 2010.

Donner, Fred M., Narratives of Islamic Origins: The Beginnings of Islamic Historical Writing, Princeton, N.J.: Darwin, 1998.

Droge, Arthur J., The Qur'ān: A New Annotated Translation, Sheffield: Equinox, 2013.

El-Achèche, Taïeb, La poésie šiite des origines au III e siècle de l'Hégire, Damascus: Presses de l'Ifpo, 2003.

Ende, Werner, "The Flagellations of Muharram and the Shicite Ulama," Der Islam 55 (1978), pp. 19-36.

van Ess, Josef, Theologie und Gesellschaft im 2. und 3. Jahrhundert Hidschra: eine Geschichte des religiösen Denkens im frühen Islam, 6 vols., Berlin: de Gruyter, 1991-1997.

Firestone, Reuven, "Shekhinah," Encyclopaedia of the Qur'ān, vol. 4, Leiden: Brill, 2004, pp. 589-591.

Fishbein, Michael, "The Life of al-Mukhtār b. Abī 'Ubayd in Some Early Arabic Historians," PhD Thesis, University of California, Los Angeles, 1988.

Fredriksen, Paula, From Jesus to Christ: The Origins of the New Testament Images of Christ, 2nd ed., New Haven: Yale University Press, 2000.

Gilliot, Claude, "Le débat contemporain sur l'islam des origines," Les débuts du monde musulman (VII ${ }^{e} X^{e}$ siècle): De Muhammad aux dynasties autonomes, ed. Thierry 
Bianquis, Pierre Guichard and Mathieu Tillier, Paris: Presses Universitaires de France, 2012, pp. 355-371.

Goitein, Shelomo D., "On the Origin of the Term Vizier," Journal of the American Oriental Society 81 (1961), pp. 425-426.

Haider, Najam, Shī Islam: An Introduction, Cambridge: Cambridge University Press, 2014.

Halm, Heinz, Shi'a Islam: From Religion to Revolution, Princeton: Marcus Wiener, 1997.

Hawting, Gerald R., "Al-Mukhtār b. Abī 'Ubayd al-Thaḳafì," Encyclopaedia of Islam, 2nd ed., vol. 7, Leiden: Brill, 1993, pp. 521-524.

Hawting, Gerald R., The First Dynasty of Islam: The Umayyad Caliphate AD 661-750, London: Routledge, 2000.

Hoyland, Robert G., In God's Path: The Arab Conquests and the Creation of an Islamic Empire, Oxford: Oxford University Press, 2015.

Hoyland, Robert G., Seeing Islam as Others Saw It: A Survey and Evaluation of Christian, Jewish, and Zoroastrian Writings on Early Islam, Princeton, N.J.: Darwin Press, 1997 .

Hylén, Torsten, "The Date of the Story of the Tawwābūn," Studia Islamica 112 (2017), pp. $175^{-205}$.

Hylén, Torsten, "Husayn, the Mediator: A Structural Analysis of the Karbala Drama according to Abū Ja'far Muḥammad b. Jarīr al-Ṭabarī (d. 310/923)," PhD thesis, Uppsala University, 2007.

Hylén, Torsten, "Mukhtār and the Mahdī: A Critical Inquiry into the Sources," $\bar{I} \bar{I} N$ : Tidsskrift for religion og kultur (2018), pp. 138-157.

Hylén, Torsten, "Myth, Ritual, and the Early Development of Shiite Identity," Intellectual History of the Islamicate World 6 (2018), pp. 300-331.

Ibn al-Nadīm, Muḥammad ibn Isḥāq, Kitâb al-Fihrist, ed. Gustav Flügel, Johannes Roediger and August Müller, Leipzig: Vogel, 1871-72.

Ibn A'tham al-Kūfī, Ahmad, Kitāb al-Futūḥ, Haydarabad: Matbaat Majlis Dairat alMaarif al-Uthmaniyah, 1972.

Ibn Sacd, Abū 'Abdallāh Muḥammad, Kitāb al-Ṭabaqāt al-Kabīr, ed. Eduard Sachau. vol. 5, Leiden: Brill, 1904-19o8.

Izutsu, Toshihiko, Ethico-Religious Concepts in the Qur'ān, Montreal \& Kingston: McGill-Queen's University Press, 2002.

Jafri, Syed Husain Mohammad, The Origins and Early Development of Shi'a Islam, Oxford: Oxford University Press, 1979.

Kohlberg, Etan, "Some Imāmī Views on the Șahāba," Jerusalem Studies in Arabic and Islam 5 (1984), pp. 143-175.

Lindstedt, Ilkka, "Sources for the Biography of the Historian Ibn A'tham al-Küf̂,", Orientalia Lovaniensia Analecta 254 (2017), pp. 299-309. 
Meyer, Birgit, “Aesthetics of Persuasion: Global Christianity and Pentecostalism's Sensational Forms," South Atlantic Quarterly 109 (2010), pp. 741-763.

Meyer, Birgit, "Mediating Absence-Effecting Spiritual Presence: Pictures and the Christian Imagination," Social Research 78 (2011), pp. 1029-1056.

Meyer, Birgit, "Religious Revelation, Secrecy and the Limits of Visual Representation," Anthropological Theory 6 (2006), pp. 431-453.

Meyer, Birgit, and Jojada Verrips, "Aesthetics," Key Words in Religion, Media and Culture, ed. David Morgan, New York, NY: Routledge, 2008, pp. 20-30.

Noth, Albrecht, and Lawrence I. Conrad, The Early Arabic Historical Tradition: A SourceCritical Study, Princeton, N.J.: Darwin, 1994.

Pellat, Charles, "Abd Allāh b. Hammām al-Salūlī," Encyclopaedia of Islam, 2nd ed., vol. 1, p. 45. Leiden: Brill, 1960.

Qadi, Wadad, Al-Kaysānīya fì-l-Tārīkh wa-l-Adab, Beirut: Dār al-Thaqāfa, 1974.

Qadi, Wadad, "The Development of the Term Ghulät in Muslim Literature with Special Reference to the Kaysāniyya," Akten des VII. Kongresses für Arabistik und Islamwissenschaft: Göttingen, 15. bis 22. August 1974, ed. Albert Dietrich, Göttingen: Vandenhoeck \& Ruprecht, 1976, pp. 295-319.

Robinson, Chase F., Abd al-Malik, Oxford: Oneworld, 2005.

Robinson, Chase F., Islamic Historiography, Cambridge: Cambridge University Press, 2003.

Rotter, Gernot, Die Umayyaden und der zweite Bürgerkrieg (68o-692), Wiesbaden: Deutsche Morgenländische Gesellschchaft, 1982.

Rubin, Uri, "Prophets and Progenitors in the Early Shica Tradition," Jerusalem Studies in Arabic and Islam 1 (1979), pp. 41-65.

Rubin, Uri, "Traditions in Transformation: The Ark of the Covenant and the Golden Calf in Biblical and Islamic Historiography," Oriens 36 (2001), pp. 196-214.

Sachedina, Abdulaziz, Islamic Messianism: The Idea of Mahdism in Twelver Shiism, Albany, NY: sunY Press, 1981.

Schoeler, Gregor, The Oral and the Written in Early Islam, London: Routledge, 2006.

Schubel, Vernon James, Religious Performance in Contemporary Islam: Shi i Devotional Rituals in South Asia, Columbia: University of South Carolina Press, 1993.

Sezgin, Ursula, Abū Mihnaf: Ein Beitrag zur Historiographie der umaiyadischen Zeit, Leiden: Brill, 1971.

Shaked, Shaul, "From Iran to Islam: On Some Symbols of Royalty," Jerusalem Studies in Arabic and Islam 7 (1986), pp. 75-91.

al-Ṭabarī, Muḥammad b. Jarīr, Tārīkh al-Rusul wa-'l-Mulūk, ed. M.J. de Goeje, H. Thorbecke, S. Fraenkel and I. Guidi, Leiden: Brill, 1879-1901.

al-Ṭabarī, Muḥammad b. Jarīr, The History of al-Ṭabarī. Vol. XIX: The Caliphate of Yazìd b. Mu'āwiyah, Albany, NY: SUNY Press, 1990. 
al-Ṭabarī, Muḥammad b. Jarīr, The History of al-Ṭabarī. Vol. XX: The Collapse of Sufyānid Authority and the Coming of the Marwānids Albany, NY: SUnY Press, 1989.

al-Ṭabarī, Muhammad b. Jarīr, The History of al-Ṭabarī. Vol. XXI: The Victory of the Marwānids, Albany, NY: SUnY Press, 1990.

Urban, Elisabeth, "The Early Islamic Mawālī: A Window onto Processes of Identity Construction and Social Change," PhD thesis, University of Chicago, 2012.

Veccia Vaglieri, Laura. "Husayn b. 'Alī b. Abī Ṭālib," Encyclopaedia of Islam, 2nd ed., vol. 3, Leiden: Brill, 1971, pp. 607-615.

Watt, W. Montgomery, "Shi'ism under the Umayyads," Journal of the Royal Asiatic Society 92 (1960), pp. 158-172.

Webb, Peter, Imagining the Arabs: Arab Identity and the Rise of Islam, Edinburgh: Edinburgh University Press, 2016.

Wellhausen, Julius, Die religiös-politischen Oppositionsparteien im alten Islam, Berlin: Weidmannsche Buchhandlung, 1901.

Wensinck, Arent Jan, A Handbook of Early Muhammadan Tradition: Alphabetically Arranged, Leiden: Brill, 1927. 